\title{
Titrimetric method determination of the content of the mass part of siliciumin feed additives
}

\author{
O. V. Moravska ${ }^{1}$, T. R. Levytskyy ${ }^{1}$, S. O. Vovk ${ }^{2}$ \\ ${ }^{1}$ State Scientific Research Control Institute of Veterinary Medical Products and Fodder Additives of Ministry \\ of Agrarian Policy and Food of Ukraine, Donetska str., 11, Lviv, 79019, Ukraine \\ ${ }^{2}$ Institute of Agriculture of Carpathian region National Academy of Agrarian Sciences of Ukraine \\ Gruschevsky str., 5, Obroshyne village, Pustomyty district, Lviv region, 81115, Ukraine
}

E-mail: olena.v.moravska@gmail.com

Received 13.01.2020 Accepted 13.02.2020

\begin{abstract}
The results of the development of the method for determining the mass fraction of silicium in powder samples of feed additives by the titrimetric method are presented in the article. The implementation and validation of the method was carried out with the use of feed additive of mixed type "Mikasil" produced by LLC «Globus», Ukraine. The procedure was reproduced ten times with the determination of the mass fraction of siliciumin two parallel samples. The method is based on the precipitation of silicic acid in the form of silicium-fluoride of potassium, followed by hydrolysis with hot water in the presence of chlorous calcium. The isolated hydrochloric acid in an amount equivalent to the content of hydro-fluoric acid is titrating with alkali solution in the presence of an indicator. The results of the studies showed that the specified method for determining the mass fraction of silicium meets the standards of accuracy control for this method, namely the standard quadratic deviation $(\sigma)$ is 0.52 , when norm up to 0.7 , when determined in two parallel samples. The results obtained indicate that the titrimetric method for determining the mass fraction of silicium in powder samples of feed additives is accurate, reliable, reproducible and economically available.
\end{abstract}

Keywords: Silicium mass fraction; Titrimetric method; Feed additive

\section{Introduction}

Silicium is one of the most common trace elements in nature. It plays an important role in the life of all living organisms, including farm animals and poultry. Silicium is a necessary element for the normal development and formation of cartilage and bone tissue, normal metabolism of fats, proteins, carbohydrates, macro- and trace elements, vitamins (Nielsen, 2014; Gotz et al., 2019). The main function of this trace element is to participate in intermediate metabolism reactions, as a catalyst for the activation of cellular energy exchange reactions, as well as an element of collagen, the main cartilage protein (Götz et al., 2019; Rodella et al., 2014). In particular, as a necessary element, silicium is located in the middle of active bone cells - osteoblasts, which synthesize the organic matrix and modify the processes of tissue calcification. X-ray microanalysis of osteoblasts showed that the bulk of silicium is concentrated in the cytoplasm and mitochondria of osteoblasts (Gotz et al., 2019). The lack of silicium in the body leads to disruption of bone and connective tissues (Jugdaohsingh et al., 2015). Experimental studies on chickens with artificial restriction of silicium in the diet, found that silicium deficient animals differed underdevelopment of the bones, articular cartilage, reduced water content in bone tissue and reduced concentration of hexosamines in cartilage. It has also been shown that in the early stages of bone tissue calcification, when the level of calcium in osteoid tissue is low, the ratio between the level of calcium and silicium is significant (Götz et al., 2019; Jugdaohsingh et al., 2015; Kotsiumbas et al., 2018).

It should be noted that one of the most important functions of silicium is its ability to form electronically-charged colloidal systems that have absorptive properties, that is, can "attach" viruses and pathogens. In addition, the normal gut microflora (lactic acid bacteria and bifidobacteria) remain in the body (Nielsen, 2014; Kulyk et al., 2010). Due to these properties, silicium is widely used in the form of absorbent feed additives based on silicium dioxide, in agriculture and poultry. At present, it is the most optimal solution to the problem of accumulation of mycotoxins, heavy metals and pesticides in the body of farm animals and poultry (Kotsiumbas et al., 2018; Fruijtier-Pölloth, 2012; Streit et al., 2012).

It should be noted that mycotoxins produced by microscopic mold fungi, which are sensitive to almost all cereals, cereals and legumes, as well as sunflower seeds. Important is, that mycotoxins are resistant to the processing of high temperature and chemicals, which is why it is difficult to deal with them. The most negative effects on the body are aflatoxins, ochratoxins, fumonisins and T-2 toxin (Grenier \& Oswald, 2011; Smith et al., 2016; Dukhnytskyi, 2011). When they enter the body with food and water, they cause disruption of basic biochemical processes, profound pathological changes of internal organs, especially in young animals, which can lead to the death of livestock (Dukhnytskyi, 2011; Grenier \& Applegate, 2013).

The peculiarity of mycotoxicosis is the difficulties of making a correct diagnosis of mycotoxin poisoning because symptoms are nonspecific. It should be noted that mycotoxicosis negatively affect the body of animals and poultry, namely, there is a weakening of the body's immunity, a decrease in reproductive function, a decrease in the gain of living weight. At the same time, the taste of eggs and meat deteriorates. As a consequence, the problem of mycotoxicosis causes great economic damage (Dukhnytskyi, 2011; 
Grenier \& Applegate, 2013; Smith et al., 2016). To prevent the negative impact of mycotoxins on the body of animals are widely used feed additives belonging to the category of additives and functional group - substances to reduce contamination of feed mycotoxins (substances that can restrain or reduce the absorption of mycotoxins, promote their excretion or modify their the mode of action) - Law of Ukraine "On feed safety and hygiene".

Particular absorption properties of feed additives based on silicium dioxide due is to the nanodispersity of particles (nano-SiO ${ }_{2}$ ) and the chemical activity of the surface (Guichard et al., 2016; Winkler et al., 2016; Fruijtier-Pölloth, 2016). At the same time, amorphous highly dispersed nano-silicium is not active, that is they do not excrete vitamins and trace elements from the body. So, nowadays silicium additives are widely used to increase productivity and maintain a healthy animal population (Amenta et al., 2015). One of such feed additives, which is becoming more and more relevant in Ukraine, as a feed additive "Mykasil", in terms of improving productivity of farm animals and poultry (meat, milk, eggs, wool), weight gain and prevention of intoxication by mycotoxins of animals and poultry is a feed additive "Mikasil" produced by LLC Globus, Ukraine.

It is a mixed type feed additive, which is a functional additive from a functional group - a substance for reducing the contamination of feed with mycotoxins and contains mainly inorganic part, which is represented by amorphous silicium dioxide $\left(\mathrm{SiO}_{2}\right)$ with a specially developed nanoporous structure of particles, obtained by technological method (Fruijtier-Pölloth, 2016) and natural inorganic sorbent - modified aluminosilicate, the presence of which allows to protect the mucous membrane of the gastrointestinal tract. It should be noted that the presence of highly active bipolar silicium dioxide $\left(\mathrm{SiO}_{2}\right)$ makes it possible to bind both polar and non-polar mycotoxins, covering the spectrum of toxins as much as possible.

Also, it was proved that additives based on silicium dioxide $\left(\mathrm{SiO}_{2}\right)$ are completely non-harmful, and are not active in the absorption and excretion of normal micro-flora, vitamins, micro- and macro-elements (Kotsiumbas, 2006).

Based on the above, it can be concluded that the control of feed additives by silicium content is a prerequisite for providing farm animals and poultry with a complete diet, which further affects the productivity and safety of animals and poultry and, as well, is the most of effective means from an economic point of view for the prevention of mycotoxicosis. There are currently the most affordable methods for determining silicium in feed additives, such as gravimetric, titrimetric and thermometric [GOST 13230.1-93]. In particular, the gravimetric method is based on the separation of silicium in the form of silicic acid from sulfuric-sour solution or chlorine-sour solution, calcinations of silicic acid to obtain silicium dioxide and removal in the form of siliciumtetrafluoride by treatment of precipitate with hydrofluoric acid.

The thermometric method is based on measuring the change in temperature of a solution as a result of a chemical reaction of precipitation of silicic acid in the form of silicium-fluoride of potassium. The method is based on the precipitation of silicic acid in the form of silicium-fluoride of potassium, followed by hydrolysis with hot water in the presence of chlorous calcium. The isolated hydrochloric acid in an amount equivalent to the content of hydro-fluoric acid is titrating with alkali solution in the presence of phenolphthalein or a mixed indicator (Nakhymova, 2001). We were analyzed the above methods and found that the most affordable from the economic point of view and from the point of view of accuracy and quality of laboratory analysis is the titrimetric method, which we used to determine the mass fraction of silicium in feed additive "Mikasil" production LLC LLC "Globus", Ozerna street, 9, Chaykivka village, Dergachiv district, Kharkiv region, 62341, Ukraine.

The aim of our work was to introduce and validate a titrometric method for determining the silicium content of feed additives.

\section{Materials and Methods}

For the introduction and validation of the method used feed additive mixed type "Mikasil" produced by LLC "Globus". The implementation of the method for determining the mass fraction of silicium by the titrimetric method was reproduced ten times, clearly complying with the general requirements for work in laboratories and requirements for the selection of powder samples of feed additives, compound feeds and premixes. Before the start of each experiment, the feed additive was mixed thoroughly and 2 samples were sampled to reproduce the procedure in two parallels, determining the arithmetic mean values and taking into account the standard quadratic deviation. Each experiment was staged according to the instructions below. Reagents were used for the experiment and solutions were prepared. In particular, hydro-fluoric acid, nitric acid, potassium chlorous, which was used to prepare a solution of 200 and $40 \mathrm{~g} / \mathrm{dm}^{3}$, which was prepared with cooled, boiled water for one hour. Calcium chlorous, which was used to prepare a solution of $400 \mathrm{~g} / \mathrm{dm}^{3}$, was neutralized with a solution of sodium hydroxide according to the indicator methyl red. Bariumchlorous was used to prepare a solution of $10 \mathrm{~g} / \mathrm{dm}^{3}$. Phenolphthalein (indicator) was used to prepare an alcohol solution of $10 \mathrm{~g} / \mathrm{dm}^{3}$ using ratified ethyl alcohol. Sodium hydroxide was used to prepare a solution of sodium hydroxide $0.25 \mathrm{~mol}^{2} \mathrm{dm}^{3}$. In particular, for solution preparation, sodium hydroxide in the amount of $10 \mathrm{~g}$ was dissolved in $1 \mathrm{dm}^{3}$ of water in a polyethylene vessel, $2 \mathrm{~cm}^{3}$ of solution of barium chlorous was added and after three days the solution was filtered and stored in a polyethylene vessel. The mass concentration of a solution of sodium hydroxide $\mathrm{C}, \mathrm{g} / \mathrm{cm}^{3}$ of silicium, was determined by a standard sample of ferro-silicium with a chemical composition corresponding to the requirements of this standard, and was calculated by the formula:

Where:

$$
\mathrm{C}=\left(\mathrm{A} \times \mathrm{m}_{\mathrm{c}}\right) /\left(\mathrm{V}-\mathrm{V}_{1}\right) \times 100
$$

A - is the certified value of the mass fraction of silicium in the standard sample, $\%$;

$\mathrm{mc}-$ is the sample mass of the standard sample, $\mathrm{g}$;

$\mathrm{V}$ - is the volume of sodium hydroxide solution used for titration of the standard sample solution, $\mathrm{cm}^{3}$;

$\mathrm{V}_{1}$ - is the volume of sodium hydroxide solution used for titration of the control sample, $\mathrm{cm}^{3}$;

The analysis was performed by weighing the sample with a weight of $0.1 \mathrm{~g}$ (with a silicium mass fraction of more than $20 \%$ ) and placed in a plastic beaker, poured $15 \mathrm{~cm}^{3}$ of water, $10 \mathrm{~cm}^{3}$ of nitric acid and $10 \mathrm{~cm}^{3}$ of hydrofluoric acid.

Further, the glass was closed with a plastic lid and the sample was dissolved without heating with stirring for 1-2 minutes. The lid was then removed and nitrogen oxides removed by blowing a pear, washing the lid and the walls of the glass. Subsequently, 10 $\mathrm{cm}^{3}$ of water was added, $40 \mathrm{~cm}^{3}$ of solution of chlorous potassium $200 \mathrm{~g} / \mathrm{dm}^{3}$ was added and stirred. The glass with the solution was cooled with running water to a temperature of $10-15^{\circ} \mathrm{C}$. The reaction resulted in a precipitate of silicium-fluoride of potassium, which was filtered on a medium density filter with a small amount of filter mass placed in a plastic funnel. The glass and sieges were washed with a refrigerated solution of chlorous potassium $40 \mathrm{~g} / \mathrm{dm}^{3}$ to neutral reaction with a universal indicator paper. By the time where from one drop of filtrate the universal paper turned yellow. The filter with sediment was then transferred to a conical flask of $500 \mathrm{~cm}^{3}$ capacities, poured $150-200 \mathrm{~cm}^{3}$ of boiling water, and $10 \mathrm{~cm}^{3}$ of solution of chlorouscalcium. The contents of the flask were thoroughly stirred to dissolve the precipitate and destroy the filter, washed the walls of the flask with boiled water, 
heated the solution to boiling and titrated with sodium hydroxide solution, in the presence of 7-10 drops of phenolphthalein solution, until appearance a steady pink color of solution.

The mass fraction of silicium (X1) in the samples was calculated by the formula in percent (\%):

Where:

$$
\mathrm{X}_{1}=\mathrm{C}\left(\mathrm{V}_{2}-\mathrm{V}_{3}\right) / \mathrm{m} \times 100
$$

$\mathrm{C}$ - mass concentration of sodium hydroxide solution, expressed in $\mathrm{g} / \mathrm{cm}^{3}$ of silicium;

$\mathrm{V}^{2}$-is the volume of sodium hydroxide solution spent on titration of solution of the sample, $\mathrm{cm}^{3}$;

$\mathrm{V}^{3}$-is the volume of sodium hydroxide solution spent on titration of the control sample, $\mathrm{cm}^{3}$;

$\mathrm{m}$ - is the sample weight, $\mathrm{g}$

The statistical processing of the results was carried out using an online calculator (medstatist.ru) - the calculation of the range of variation with definition the mean values $(\mathrm{M})$, the arithmetic error $(\mathrm{m})$, the standard quadratic deviation $(\sigma)$, the median $(\mathrm{Me})$ and the coefficient of variation $(C)$.

\section{Results and Discussion}

Figure 1 shows the content of the mass fraction of silicium $\left(X_{1}\right)$, calculated as a percentage, in two parallels at each test setting, followed by the determination of the arithmetic mean values, standard quadratic deviation, median, and the coefficient of variation.

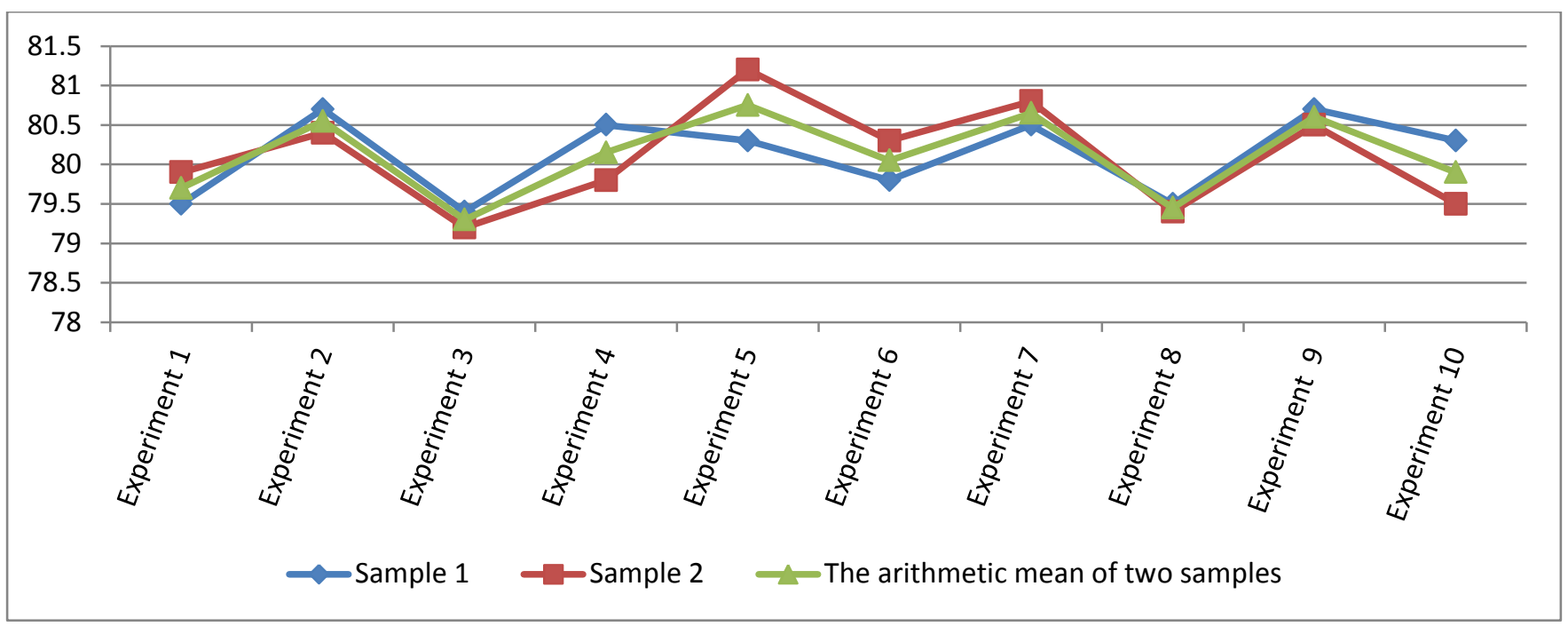

Figure 1. The content of the mass fraction of silicium in parallel samples of feed additive "Mikasil", \%.

From the data in Table 1 it can be seen that the standard quadratic deviation of each arithmetic mean values of two parallel samples in each of the ten experiments is within the limits of the accuracy control standards for determining the mass fraction of silicium by this method. Note that according to the requirements of the precision control standards for a feed additive, where the mass fraction of silicium dioxide is more than $50 \%$, the standard deviation, when determined in two parallels, should be no more than 0.7. After analyzing the results of each experiment (Table 1), with respect to the accuracy control standards for this method, namely the standard quadratic deviation does not exceed 0.7 , we calculated the arithmetic mean values for ten experiments conducted in two parallel samples. The arithmetic mean value content of the mass fraction of silicium (\%) in the feed additive "Mikasil" ( $(n=10) ;(M \pm m)$ is $80.11 \pm 0.17$, where the standard quadratic deviation $(\sigma)$ is 0.52 and the coefficient of variation (Sv) is $0.65 \%$. We will note that in the characteristic of the product of the feed additive "Mikasil" it is stated that the content of silicium dioxide is not less than $78 \%$, which was confirmed by our studies, by the values of which the silicium content is $80.11 \%$.

Table 1. The arithmetic mean value of the content of the mass fraction of silicium of two parallel samples of the feed additive "Mikasil", \%.

\begin{tabular}{lllll}
\hline $\begin{array}{l}\text { Experiment } \\
\text { number }\end{array}$ & $\begin{array}{l}\text { The arithmetic mean value of the } \\
\text { content of the mass fraction of silicium } \\
\text { of two parallel samples, \%, } \mathbf{( M} \pm \mathbf{~ m )}\end{array}$ & $\begin{array}{l}\text { Standard } \\
\text { quadratic } \\
\text { deviation, } \mathbf{( \sigma )}\end{array}$ & $\begin{array}{l}\text { Median(Me), } \\
\mathbf{( x ) = 1 / 2}\end{array}$ & $\begin{array}{l}\text { The coefficient of } \\
\text { variation }(\mathbf{C v}), \boldsymbol{\%} \\
\mathbf{C v}=\mathbf{\sigma} / \mathbf{M} \times \mathbf{1 0 0}\end{array}$ \\
& & & & \\
1 & $79.70 \pm 0.28$ & 0.28 & 79.70 & 0.35 \\
2 & $80.55 \pm 0.21$ & 0.21 & 80.55 & 0.26 \\
3 & $79.30 \pm 0.14$ & 0.14 & 79.30 & 0.18 \\
4 & $80.15 \pm 0.49$ & 0.49 & 80.15 & 0.62 \\
5 & $80.75 \pm 0.64$ & 0.64 & 80.75 & 0.79 \\
6 & $80.05 \pm 0.35$ & 0.35 & 80.05 & 0.44 \\
7 & $80.65 \pm 0.21$ & 0.21 & 80.65 & 0.26 \\
8 & $79.45 \pm 0.07$ & 0.07 & 79.45 & 0.09 \\
9 & $80.60 \pm 0.14$ & 0.14 & 80.60 & 0.18 \\
10 & $79.90 \pm 0.57$ & 0.57 & 79.90 & 0.71 \\
\hline
\end{tabular}




\section{Conclusion}

From the above data, we can conclude that the titrimetric method for determining the mass fraction of silicium in powdered feed additives is completely reproducible, accurate, reliable and economically feasible. Consequently, the titrimetric method for determining the mass fraction of silicium is reliable and can be used to determine the percentage content of silicium dioxide $\left(\mathrm{SiO}_{2}\right)$ in powder additives. The work is a fragment of the research projects "Development and implementation of a feed safety control system and fodder additives", state registration № 0117-U000948 of State Scientific Research Control Institute of Veterinary Medical Products and Fodder Additives of Ministry of Agrarian Policy and Food of Ukraine.

\section{References}

Amenta, V., Aschberger, K., Arena, M., Bouwmeester, H., Botelho Moniz, F., Brandhoff, P., Gottardo, S., Marvin, H. J., Mech, A., Quiros Pesudo, L., Rauscher, H., Schoonjans, R., Vettori, M. V., Weigel, S., \& Peters, R. J. (2015). Regulatory aspects of nanotechnology in the agri/feed/food sector in EU and non-EU countries. Regul. Toxicol. Pharmacol, 73(1), 463-76. doi:10.1016/j.yrtph.2015. 06. 016

Dukhnytskyi, V. B., Khmelnytskyi, H. O., Boiko, H. V., \& Ishchenko, V. D. (2011). Veterinarian Mycotoxicology: A Tutorial. K.: Ahrarna osvita, 240 c. (in Ukrainian).

Fruijtier-Pölloth, C. (2012). The toxicological mode of action and the safety of synthetic amorphous silica-a nanostructured material. Toxicology, 294(2-3), 61-79. doi: 10.1016/j.tox.2012.02.001

Fruijtier-Pölloth, C. (2016). The safety of nanostructured synthetic amorphous silica (SAS) as a food additive (E 551). Arch. Toxicol., 90(12): 2885-2916.

Götz, W., Tobiasch, E., Witzleben, S., \& Schulze, M. (2019). Effects of Silicon Compounds on Biomineralization, Osteogenesis, and Hard Tissue Formation. Pharmaceutics, 11(3): E117. doi: 10. 3390 / pharmaceutics 11030117

Grenier, B., \& Oswald, I.(2011). Mycotoxin co-contamination of food and feed: meta -analysis of publications describing toxicological interactions. World Mycotoxin Journal, 4: 285-313. doi. Org / 10. 3920 / wmj 2011.1281.

Grenier, B., \& Applegate, T. J. (2013). Modulation of intestinal functions following mycotoxin ingestion: Meta-analysis of published experiments in animals. Toxins (Basel)., 5(2) : 396-430. doi: 10.3390/toxins5020396.

Guichard, Y., Fontana, C., Chavinier, E., Terzetti, F., Gaté, L., Binet, S., \& Darne, C. (2016). Cytotoxic and genotoxic evaluation of different synthetic amorphous silica nanomaterials in the V79 cell line. Toxicol. Ind. Health., 32(9), 1639-50. doi: $10.1177 / 0748233715572562$.

Jugdaohsingh, R., Watson, A. I., Bhattacharya, P., van Lenthe, G. H., \& Powell, J. J. (2015). Positive association between serum silicon levels and bone mineral density in female rats following oral silicon supplementation with monomethylsilanetriol. Osteoporos int., 26(4), 1405-1415. doi: 10.1007/s00198-014-3016-7.

Kotsiumbas, I. Y. (2006). Pre-clinical studies of veterinary medicinal products. Lviv: Triada plius. (in Ukrainian).

Kotsiumbas, I. Y., Patereha, I. P., Zhyla, M. I., Kystsiv, O. S., \& Kabanets, A. S. (2018). Study of sorbent based on silicon dioxide: determination of toxicity parameters. Ntbibt., 19(2), 178-182. (in Ukrainian).

Kulyk, M. F., Obertiukh, Y. V., Zaiets, A. P., Herasymchuk, A. I., Khryplyvyi, V. V., \& Kostetska, Y. V. (2010). Complexes of silicon with trace elements - a new direction of balancing the mineral nutrition of animals. Kormy i kormovyrobnytstvo, 66, 328-337. (in Ukrainian).

Nakhymova, L. Y. (2001). Interstate standard. Ferrosilicon. Methods for the determination of silicon. Moscow: IPK Izdatelstvo standartov. (in Russian).

Nielsen, F. H. (2014). Update on the possible nutritional importance of silicon. J. Trace. Elem. Med. Biol., 28(4), 379-82. doi: 10. 1016 /j. jtemb. 2014. 06. 024.

Rodella, L. F., Bonazza, V., Labanca, M., Lonati, C., \& Rezzani, R. (2014). A review of the effects of dietary silicon intake on bone homeostasis and regeneration. J. Nutr. Health. Aging., 18(9), 820-6. doi: 10.1007/s12603-014-0484-6.

Smith, M. C., Madec, S., Coton, E., \& Hymery, N. (2016). Natural Co-Occurrence of Mycotoxins in Foods and Feeds and Their in vitro Combined Toxicological Effects. Toxins (Basel), 8(4), 94. doi: 10.3390/toxins8040094.

Streit, E., Schatzmayr, G., Tassis, P., Tzika, E., Marin, D., Taranu, I., Tabuc, C., Nicolau, A., Aprodu, I., Puel, O., \& Oswald, I. (2012). Current Situation of Mycotoxin Contamination and Cooccurrence in Animal Feed-Focus on Europe. Toxins (Basel), 4(10): 788-809.

Winkler, H. C., Suter, M., \& Naegeli, H. (2016). Critical review of the safety assessment of nano-structured silica additives in food. J. Nanobiotechnology, 14(1), 44. doi:10.1186/s12951-016-0189-6.

\section{Citation:}

Moravska, O.V., Levytskyy, T.R., Vovk, S.O. (2020). Titrimetric method determination of the content of the mass part of siliciumin feed additives. Under urban ecosystem. Ukrainian Journal of Ecology, 10(1), 62-65.

\begin{tabular}{|ll}
$(\mathrm{cc}) \mathrm{Br}$ \\
$\mathrm{Br}$
\end{tabular} 